\title{
Sistem Informasi E-Office Pendukung Program Paperless Korespondensi Perkantoran (Studi Kasus: Bagian Administrasi Akademik Akademi Komunitas Semen Indonesia Gresik)
}

\author{
Totok Mulyono ${ }^{1}$, Kholid ${ }^{2}$ \\ ${ }^{1,2}$ Program Studi Otomasi Perkantoran \\ Akademi Komunitas Semen Indonesia Gresik \\ E-mail: ${ }^{1}$ totokmulyono@aksi.ac.id, 2drs.kholid@yahoo.co.id
}

\begin{abstract}
Abstrak
Elektronik office (e-office) sebagai salah satu hasil dari perkembangan teknologi tentunya akan membantu pegawai di kantor dalam menyelesaikan tugas-tugas perkantoran. Tidak hanya pegawai, tetapi para pemimpin pun juga akan ikut menikmati hasilnya sehingga dapat menghasilkan laporan yang dapat di-generate dengan cepat berdasarkan data terpadu yang ada didalam sistem e-office. Pemanfaatan e-office masih kurang berkembang karena budaya dan perilaku pegawai yang masih konvensional. Metodologi penelitian ini menggunakan SDLC dan hasil yang diharapkan adalah aplikasi berbasis web yang dibangun dapat memudahkan pegawai dalam melakukan pencarian dokumen yang dikehendaki dan apabila dokumen telah diketemukan maka dokumen dapat di unduh dan dilakukan disposisi ke pegawai yang lain. Hasil penelitian menunjukkan bahwa aplikasi e-office berupa surat masuk dan surat keluar serta disposisi memudahkan pegawai mengurus administrasi perkantoran khususnya dokumen persuratan dan korespondensi sehingga surat dapatdiproses secara cepat dan efisien.
\end{abstract}

Kata Kunci-E-office, Paperless, Kegiatan Perkantoran.

\section{PENDAHULUAN}

Electronic Office (e-office) adalah suatu sistem yang berhubungan dengan administrasi yang secara maya memusatkan komponen-komponen sebuah organisasi, di mana data, informasi dan komunikasi dibuat melalui media telekomunikasi.Seiring perkembangan zaman serta dengan kebijakan penerapan reformasi birokrasi di Indonesia yang mewajibkan setiap proses bisnis atau kegiatan kantor harus berjalan dengan efisien dan efektif yang menyebabkan terjadinya transformasi proses bisnis dari sistem konvensional atau manual ke sistem otomatisasi. Proses bisnis yang dilakukan secara manual (document driven)menggambarkan pengiriman sebuah dokumen, misalnya surat yang masih berupa hardcopy, dan dikirimkan dengan kurir antar unit di lingkungan kantor(Arief, 2005).

E-office sebagai salah satu hasil dari pekembangan teknologi tentunya akan membantu pegawai di kantor dalam menyelesaikan tugas-tugas mereka. Tidak hanya pegawai, tetapi para pemimpin pun juga akan ikut menikmati hasilnya misalnya menghasilkan laporan yang dapat di-generate dengan cepat berdasarkan data terpadu yang ada didalam sistem e-office. Sistem e-office selain meminimalisasipenggunaan kertas (paperless), e-office juga mempermudah penyimpanan dan pengolahan data di 
dalam suatu kantor karena data menjadi terpusat (centralized) dengan bantuan database sehingga data yang ada akan saling terhubung dan menjadi kesatuan utuh yang dapat memberikan informasi bagi pegawai kantor. Selain data tentunya penggunaan komputer bagi para pegawai juga mutlak diperlukan demi terciptanya sistem eoffice(Oktaf \& Hendrixon, 2017).

Paperless adalah mengurangi pemakaian kertas bukan meniadakan pemakaian kertas sama sekali. Jadi diharapkan kiranya konsep Paperless tidak diterjemahkan dengan arti"Bebas Kertas". Karena hampir tidak mungkin bagi sebuah kantor untuk tidak menggunakan kertas dalam menjalankan tugas administrasi perkantorannya. Konsep ini merupakan hasil pemikiran yang muncul selain sebagai akibat berkembangnya teknologi informasi dan komputer juga merupakan sebuah solusi untuk mengurangi penggunaan filling kabinet sebagai tempat penyimpanan arsip dan merupakan pekerjaan yang memakan waktu terlalu lama (Afeanpah, 2017).

Bagian Administrasi Akademikmemiliki peranan dalam melayani kegiatan yang berkaitan dengan administrasi perkantoran, seperti pengelolaan surat-menyurat dan pengarsipan dokumen-dokumen penting.Pengolahan surat masih menggunakan sistem komputerisasi sederhana (Microsoft Excel) seperti aktifitas mengolah data surat masuk dan keluar yang masih dalam bentuk kertas sehingga memungkinkan rusak atau hilangnya dokumen tersebut dan penggunaan kertas dapat menambah biaya pengeluaran untuk pemakaian yang berlebihan.

Mekanisme paperless memiliki manfaat yang dapat dirasakanBagian Administrasi Akademik diantaranya efisiendalam penggunaan waktu, efisien terhadap biaya, meminimalisasi penggemukan prosedur, manajemen kerja yang lebih baik, mempermudah dalam pengkoordiniran kerja,dan citra institusi yang lebih baik serta meningkatkanefisiensi pekerjaan dilingkungan Akademi Komunitas Semen Indonesia (AKSI) Gresik.

Tujuan penelitian ini adalah merancang e-office dan implementasi e-office serta implikasi dari penerapan e-office sehingga meminimalisasitenagadalam pendistribusian dokumen, mengurangi kebutuhan alat tulis kantor, database penyimpanan yanglebih baik dan terstruktur agar pencariandokumen dapat lebih cepat serta tidakmemerlukan ruangan tambahan.

\section{METODE PENELITIAN}

Metodologi dalam penelitian ini menggunakan metode SDLC (system developemtn life cycle) yang dikemukan oleh O'Brien dan George M Marakas yang dikutip oleh Rusiyani memiliki 5 tahapan yaitu 1) investigasi sistem, langkah ini adalah memproses pengembangan sistem denganmempertimbangkan teknologi sebagai solusi sistem informasi yang telah ditetapkan; 2) analisis sistem, langkah ini adalah penguraian hasil identifikasi sistem dan di analisis mengenai kebutuhan user (pengguna) dan memilih alternative metode pemecahan masalah serta merencanakan dan menerapkan rancangan sistem yang dikembangkan; 3) design sistem, langkah ini adalah merancang sistem secara spesifikasi yang memuat pada input, proses dan output yang dihasilkan sistem dan berkolaborasi terhadap software, hardware, network, dataware dan brainware sebagai pemenuhan syarat pengembangan model yang logis dari sistem yang baru; 4) Implementasi sistem, langkah ini adalah langkah pengujian sistem dengan cara melatih orang-orang yang mengoeprasikan dan menggunakan sistem tersebut serta melakukan pengelolaan terhadap perubahan sistem kepada pengguna akhir; 5) Pemeliharaan sistem, langkah ini adalah langkah memelihara sistem yang sudah berjalan dan apabila mengalami kendala-kendala maka dapat ditinjau kembali sistem tersebut. 


\section{HASIL DAN PEMBAHASAN}

\subsection{Perancangan aplikasi e-office}

Sebelum melakukan pembangunanaplikasi e-office tahapan awal yang dilakukan adalah membuat rancangan sistem. Tahapan penyusunan rancangan dilakukan meliputi: (1). Penyusunan analisa kebutuhanpengguna., dan (2). Penyusunan analisa kebutuhan minimum sistem (Minimum Requirement)

Proses Bisnis pelaksanaan kegiatan e-officeberdasarkan Peraturan Akademik Tahun 2015 Tentang Pedoman Tata Persuratan diLingkungan Akademi Komunitas Semen Indonesia Gresik. Pelaksanaanalur surat masuk yang dilakukandalampelaksanaan yang terjadi, terdapat suratmasuk diterima oleh "Penerima" laludiarahkan "Pengarah" dan dicatat"Pelaksana". Selanjutnya surat terebutditindak lanjuti oleh "Pengarah". Prosestindak lanjut dilakukan olehpengarah yakni pelaku-pelaku yangakan berwenang dalam sistem tersebut.

\section{Penerima $\Rightarrow$ Pengarah $\Rightarrow$ Pencatat}

Gambar 1. Proses bisnis dokumen

\section{Aspek Fungsional}

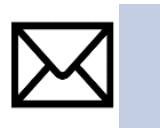

Surat

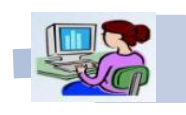

mencatat dan scan

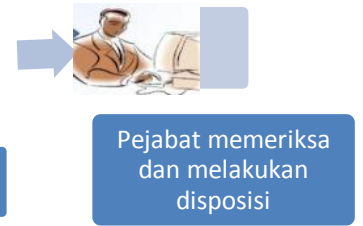

Gambar 2. Alur surat

Terdapat tiga user dalam aplikasi yakni userAdmin, User Wadir, User Kaprodi.

1. User BAAK

BAAK dalam aplikasi tersebutmerupakan staf umum yang menerimasurat masuk dan kemudian melakukaninput ke dalam aplikasi tersebut. Adapunfitur dari Aplikasi tersebut yang dapatdiakses oleh Admin yakni :

- Melakukan input surat masuk ke dalam aplikasi

- Melakukan input surat keluar ke dalam aplikasi

- Mengetahui surat yang terlah diproses

- Mengetahui surat yang belum diproses

- Melakukan pengubahan terhadap password akun 


\section{User Direktur}

Direktur yakniuser yang akan menindaklanjuti suratyang telah diinput oleh BAAK.Tindaklanjut berupa disposisi suratlangsung ke bagian atau surat tersebutdilanjutkan ke Wakil Direktur.Berikut fitur yang dapat dilakukan olehDirektur:

- Mengetahui Disposisi surat masuk

- Menanggapi surat masuk dan menindaklanjuti ke Wakil Direktur atau ke bagian Lain

- Mengetahui surat masuk yang telah di proses

- Mengetahui surat keluar yang telah di proses

- Mengetahui surat masuk yang belum diproses

- Mengetahui surat keluar yang belum diproses

- Mengetahui tindak lajut surat masuk

- Mengetahui tindak lajut surat keluar

- Mengetahui surat yang telah diproses dan tindak lanjut

3. User Wakil Direktur

Wakil Direktur(wadir) merupakanuser memberikan disposisi surat.Wadir melakukan disposisike pelaksana dari surat tersebut. AdapunUser wadir dapat melakukan aksessebagai berikut :

- Mengetahui Surat masuk

- Melakukan disposisi/tindak lanjut terhadap surat masuk

- Mengetahui surat masuk yang telah ditindaklanjut

4. User Ketua Program Studi

User Ketua Program Studi (kaprodi) merupakan userketua program studi yang akan menindaklanjutisurat masuk. Adapun user bidang dapatmelakukan akses sebagai berikut

- Melakukan disposisi/tindak lanjut terhadap surat masuk

- Melakukan disposisi/tindak lanjut terhadap surat keluar

Berdasarkan Analisa KebutuhanSistem dalam pembuatan aplikasi, didapatkebutuhan sistem meliputi :

- Perangkat lunak pengembangan aplikasi. Software Development PHP versi 5.0. Menggunakan web server Apache 2.2.11.

- Perangkat Lunak pengembangan database Database My SQL 5.0

- Sistem minimum dan konfigurasi aplikasi disis pengguna. Operating System Windows. Ram $256 \mathrm{Mb}$. Browser. Internet.

\section{Pembuatan Aplikasi e-office}

Setelah melalui prosesperancangan aplikasi, maka prosesselanjutnya adalah pembuatan aplikasi.Aplikasi dapat diakses melalui jaringanintranetdengan autentifikasi oleh database diserver.

Berikut adalah antarmuka halamanutama dari aplikasi. Dalam halaman iniuser dapat melakukan fungsionalitas dariaplikasi e-office. 


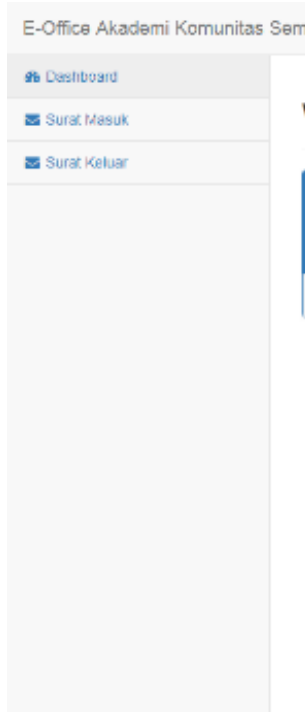

Welcome, Melur Belinda!

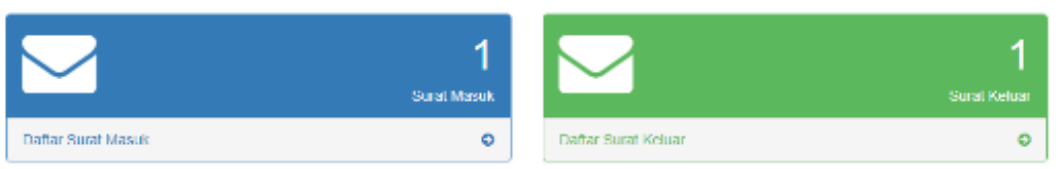

Gambar 3. Tampilan Aplikasi e-office

Berikut adalah halaman BAAK dalam melakukan input surat masukpada aplikasi eoffice online

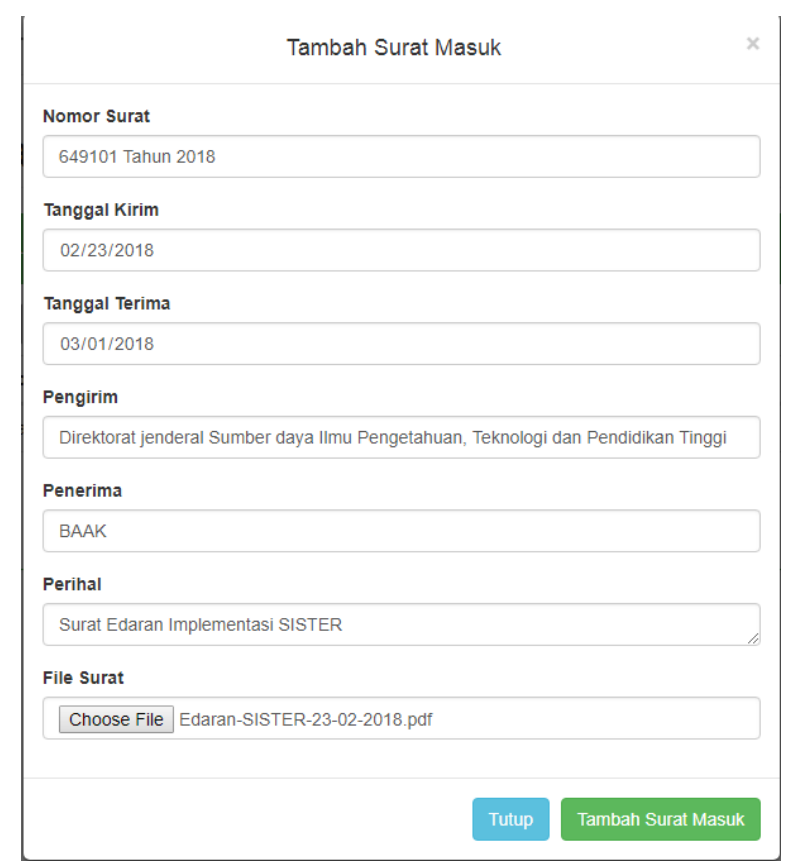

Gambar 4.Tampilan Input Surat Masuk

Berikut adalah halaman BAAK dalam melakukan input surat keluarpada aplikasi eoffice online 


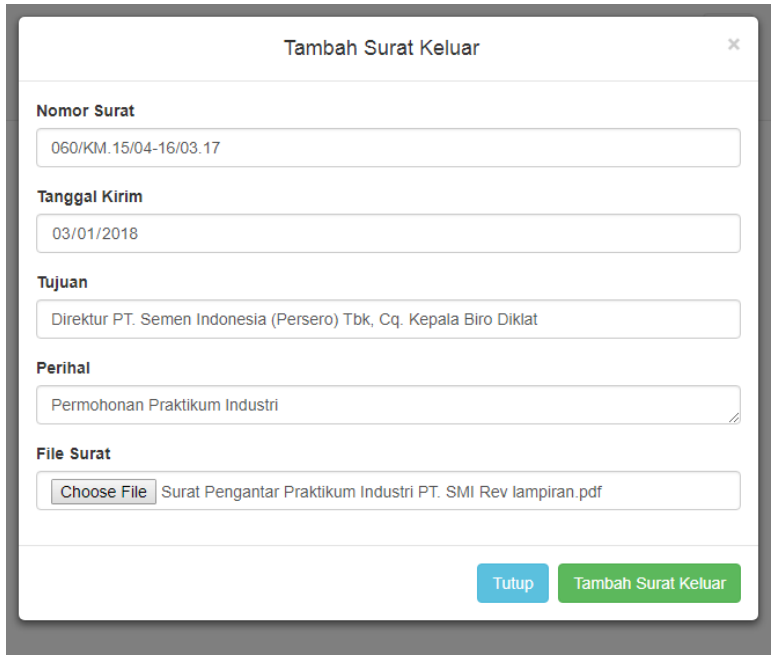

Gambar 5.Tampilan Input Surat Keluar

Berikut halaman proses pencariansurat masuk. Dalam halaman tersebut user dapatmencari surat berdasarkan varibel tertentuseperti nomor, tanggal, pengirim, asal surat sertaperihal surat.

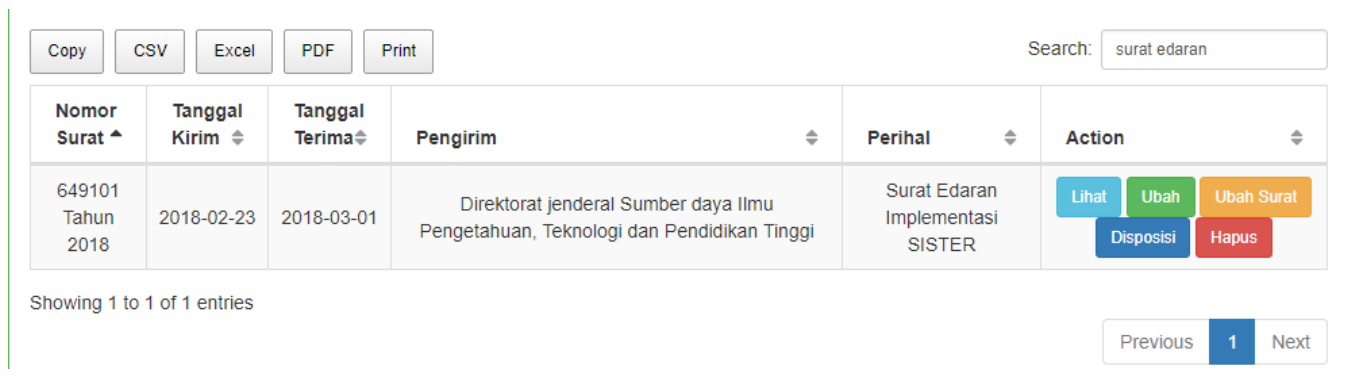

Gambar 6. Tampilan Pencarian Surat Masuk

Berikut halaman proses pencariansurat keluar. Dalam halaman tersebut user dapatmencari surat berdasarkan varibel tertentuseperti nomor, tanggal, pengirim, asal surat serta perihal surat.

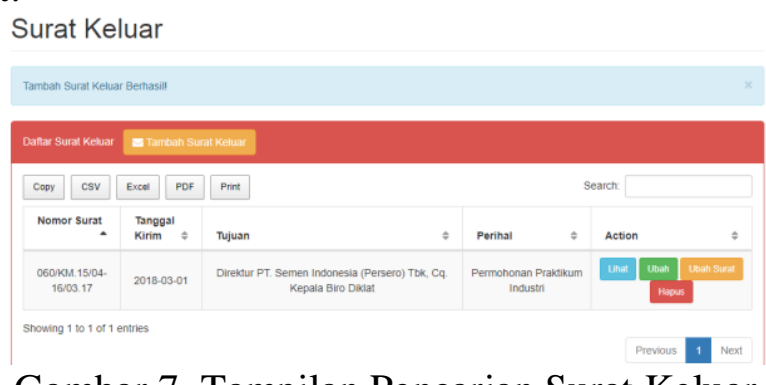

Berikut halaman proses disposisisuratmasuk. Dalam halaman tersebut user dapatmencari surat berdasarkan varibel tertentuseperti nomor, tanggal, pengirim, asal surat serta perihal surat. 


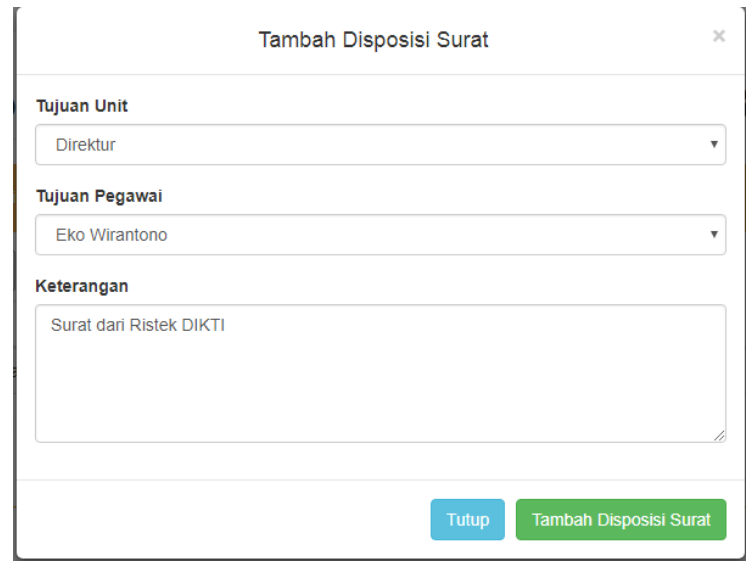

Gambar 8. Tampilan Disposis Surat Masuk

Fasilitas yang terdapat padaaplikasi e-office, bertujuan untukdapat memberikan kemudahan terhadapefisiensi dan efektifitras kegiatanadministrasi perkantoran.

Penerapan aplikasi e-officedibagian administrasi akademik Akademi Komunitas Semen Indonesia Gresik dengane-office pada khususnya tidaklahmudah. BAAK perlu melakukansosialisasi dan "reminder" ke tiap useruntuk menggunakan membuka aplikasitersebut. Budaya kerja yangmenggunakan sistem manual masihmelekat pada pegawai.Meskipun penerapan e-office belumsecara penuh dilakukan diBAAK, namun penerapan tersebuttelah menunjukkan peningkatanefektifitas dan efisiensi kegiatanperkantoran. Hal ini terlihat dari evaluasiterkait implikasi terhadap beberapa Tabel 2 berikut.

Tabel 2. Indikator Kinerja Penerapan e-office BAAK

\begin{tabular}{|c|c|c|c|c|}
\hline No & Indikator & Sebelum e-office & Sesudah e-office & Keterangan \\
\hline 1 & $\begin{array}{l}\text { Pembelian } \\
\text { Alat Tulis } \\
\text { Kantor }\end{array}$ & $100 \%$ & $70 \%$ & $\begin{array}{l}\text { Alat Tulis Kantor } \\
\text { dapat dihemat sebesar } \\
30 \%\end{array}$ \\
\hline 2 & $\begin{array}{l}\text { Kecepatan } \\
\text { Transfer } \\
\text { Dokumen }\end{array}$ & $\begin{array}{l}\text { 8-40 jam kerja * } \\
(40 \text { Jam Kerja } \\
=100 \%)\end{array}$ & $\begin{array}{l}\text { 1-12 Jam Kerja } \\
(12 \text { Jam } \\
\text { Kerja=30\%) }\end{array}$ & $\begin{array}{l}\text { Mempercepat waktu } \\
\text { transfer dokumen } \\
\text { sebesar } 70 \%\end{array}$ \\
\hline 3 & $\begin{array}{l}\text { Kecepatan } \\
\text { pengambilan } \\
\text { keputusan }\end{array}$ & $\begin{array}{l}\text { 8-40 Jam Kerja } \\
\text { *(40 Jam } \\
\text { Kerja }=100 \%)\end{array}$ & $\begin{array}{l}\text { 1-12 Jam Kerja } \\
(12 \text { Jam } \\
\text { Kerja=30\%) }\end{array}$ & $\begin{array}{l}\text { Mempercepat waktu } \\
\text { transfer dokumen } \\
\text { sebesar } 70 \%\end{array}$ \\
\hline 4 & $\begin{array}{l}\text { Tempat } \\
\text { Penyimpanan } \\
\text { Dokumen }\end{array}$ & Ruangan $3 \times 5 \mathrm{~m}^{2}$ & Storage $1 \mathrm{~Tb}$ & $\begin{array}{l}\text { Surat Tersimpan } \\
\text { dalam } \\
\text { Database Surat Masuk } \\
\text { dan surat keluar } \\
\text { berbentuk Elektronik }\end{array}$ \\
\hline
\end{tabular}




\section{KESIMPULAN}

Penerapan e-office padabagian administrasi akademik sebagai bagiandari program paperless korespondensi perkantoran sangat membantuterutama proses pengambilan keputusankebijakan. Berdasarkan hasil penelitian daripenerapan e-office yang telahdilakukan bagian administrasi akademik memberikan dampak terhadap ;

1. Distribusi surat masuk dan surat keluar lebih cepat sehingga disposisi surat dapat langsung ditinjaklanjuti.

2. ATK dan sarana fisik penyimpanan dokumen yang digunakan berkurang.

Database administrasi surat masuk dan surat keluar dilakukan secara online. Database tersebut dapat membantu proses input-update dengan mudah serta proses pencarian surat masuk dan surat keluar dilakukan dengan cepat.

\section{DAFTAR PUSTAKA}

[1]. Afeanpah, F. (2017, Januari ). Komentar Tentang Paperless Office. Retrieved from Paperless Office: https://prastowo.staff.ugm.ac.id/?modul=baca\&dir=artikel\&artikel=Paperless-Office [2]. Arief, M. R. (2005). SISTEM e-OFFICE UNTUK MENDUKUNG KOMUNIKASI, KOORDINASI DAN ALOKASI SUMBER DAYA (Studi Kasus di KPTU FT UGM). Jurnal Dasi September 2005, p. 7.

[3]. Dewandaru, D. S. (2013). Pemanfaatan Aplikasi E-Office Untuk Mendukung Penerapan E-Government Dalam Kegiatan Perkantoran Studi Kasus: Puslitbang Jalan Dan Jembatan. Seminar Nasional Teknologi Informasi dan Komunikasi 2013 (SENTIKA 2013) (pp. 232-239). Yogyakarta: Universitas Atma Jaya Yogyakarta.

[4] O. J., \& Hendrixon. (2017). Penerapan E-Office Dalam Administrasi Perkantoran (Studi Kasus : Balitbangda Prov. Sumsel). Jurnal Pembangunan Nagari Volume 2 Nomor 1 Edisi Juni 2017, pp. 75-84. 